\title{
PENGEMBANGAN MODEL PEMBELAJARAN PERMAINAN MOTORIK HALUS UNTUK ANAK USIA DINI
}

\author{
Arief Darmawan ${ }^{1}$, Amir Maulana $^{2}$ \\ 1,2 Universitas Islam " 45 " Bekasi \\ Email: arief.fik.um@gmail.com¹, damir46@gmail.com² \\ DOI: https://doi.org/10.36526/kejaora.v4i2.721
}

\begin{abstract}
ABSTRAK
Tujuan penelitian ini untuk mengembangkan model pembelajaran permainan motorik halus anak usia dini. Metode Penelitian yang digunakan menggunakan metode penelitian R \& D dari Borg \& Gall yang sudah dimodifikasi menjadi 7 langkah. Berdasarkan analisis kebutuhan yang dilakukan oleh peneliti yang berupa pengamatan, wawancara dan penyebaran angket, ditemukan beberapa permasalahan yang dihadapi yaitu kurangnya contoh atau model permainan yang menekankan pada aspek motori halus untuk anak dini. hasil penelitian dari analisis kebutuhan, uji coba produk awal, tinjauan ahli, uji coba kelompok kecil, dan uji coba kelompok besar yang dilakukan maka diperoleh data penelitian. Data tersebut dikumpulkan dan diolah sehingga dihasilkan sebuah produk yaitu model pembelajaran motorik halus anak usia dini. Adapun contoh model permainannya antara adalah: 1.Menghitung menggunakan jari, 2.Bermain dengan gelang karet, 3. Tebak bola warna Memakai telunjuk jari, 4. Melempar bola, 5. Bermain dengan kertas, 6. Membedakan besar kecil, 7. Bermain dengan lilin, 8. Membedakan panjang pendek, 9. Membedakan bentuk benda, 10. Pesan berantai, 11. Pengenalan huruf, 12. Mencocokkan gambar dengan angka.13. Permainan Dadu angka. Hasil dari uji kecil dan uji besar adalah model layak dan dapat digunakan dengan baik.
\end{abstract}

Keywords: Pengembangan, model, Pembelajaran, Motorik Halus

\section{PENDAHULUAN}

Ki Hadjar Dewantara pernah memberikan semboyan ing ngarsa sung tulada, ing madya mangun karsa, tut wuri handayani. Di akhir kalimat tersebut menarik mengingat arti dari tut wuri handayani yaitu di belakang memberikan semangat atau dorongan. Artinya para guru selain mengajar seyogyanya juga memberikan semangat atau dorongan kepada para peserta didiknya. Pendidikan merupakan suatu kegiatan universal dalam kehidupan manusia. Konsep pendidikan sepanjang hayat menjadi panduan dalam meninggikan harkat dan martabat manusia. Anak-anak bangsa tidak boleh tertinggal dengan bangsa lainnya di dunia. Oleh karena itu, pendidikan sejak dini harus ditanamkan pada mereka. Pendidikan anak usia dini adalah pendidikan yang cukup penting dan bahkan menjadi landasan kuat untuk mewujudkan generasi yang cerdas dan kuat. PAUD merupakan salah satu bentuk penyelenggaraan pendidikan yang menitikberatkan pada peletakan dasar ke arah pertumbuhan dan perkembangan fisik (koordinasi motorik halus dan kasar), kecerdasan, sosio emosional, bahasa dan komunikasi, sesuai dengan keunikan dan tahap-tahap perkembangan yang dilalui oleh anak usia dini.

Pembinaan dan pengembangan potensi anak bangsa dapat diupayakan melalui pembangunan di berbagai bidang yang didukung oleh atmosfer belajar (Cameron et al., 2012; Krampe, 2002; Piek, Dawson, Smith, \& Gasson, 2008). Anak prasekolah kedudukannya sebagai tunas bangsa dan penerus cita-cita perjuangan bangsa perlu mendapatkan posisi dan fungsi strategis dalam pembangunan. Terutama pembangunan pendidikan yang menjadi bagian integral dalam pembangunan suatu bangsa dan kunci pembangunan potensi anak yang seyogyanya dilaksanakan dalam keluarga, sekolah, dan masyarakat. Masamasa pada rentangan usia dini merupakan masa emas dimana perkembangan fisik, motorik, kognitif, emosional, bahasa dan 
sosial berlangsung dengan sangat cepat.(Kawai et al., 2015; Wolpert, Diedrichsen, \& Flanagan, 2011; Wolpert, Ghahramani, \& Flanagan, 2001) aspek motorik kasar,motorik halus dan kognitif pada anak usia dini memang harus dikembangkan sedini mungkin. Namun dengan proses pembelajaran yang semudah mungkin dan sesederhana mungkin (Ghassabian et al., 2016; Langendorfer, 2016; McDowell, 2008; Pitcher, Piek, \& Hay, 2003).

$$
\text { Berdasarkan observasi yang }
$$
dilakukan oleh peneliti yang berupa pengamatan, wawancara dan penyebaran angket secara langsung oleh Guru Paud ditemukan beberapa permasalahan yang dihadapi yaitu kurangnya sumber belajar yang menekankan pada aspek motorik halus anak didik, sehingga perkembangan anak usia dini tersebut menjadi kurang. Anak usia dini sangat aktif bergerak dan juga anak tersebut lebih suka dengan permainan untuk itu peneliti membuat sebuah metode baru tentang bagaimana sebuah permainan dapat mengasah kemampuan motorik kasar,motorik halus dan kognitif anak tersebut.

Guru membutuhkan sebuah fasilitas pembelajaran atau media pembelajaran guna untuk memberikan pengajaran secara maksimal. Motorik terbagi menjadi dua yaitu motorik kasar dan motorik halus. motorik kasar adalah kemampuan tubuh dalam melakukan kegiatan sebagian besar menggunakan seluruh bagian tubuh dan memerlukan tenaga yang besar karena dilakukan oleh otot-otot besar yang meliputi gerak dasar lokomotor, non lokomotor, dan manipulatif. Sedangkan motorik halus adalah kemampuan tubuh dalam melakukan kegiatan hanya melibatkan bagian-bagian tubuh tertentu saja dan dilakukan otot-otot kecil, karena itu tidak memerlukan tenaga yang besar, contohnya dalah menggunting, menggambar, tepuk tangan, melambaikan tangan, dan sebagainya.(Harvey, 2017; Sun, Sun, Zhu, Huang, \& Hsieh, 2011; Westendorp, Houwen, Hartman, \& Visscher, 2011)

Tabel 1. Modul kegiatan Aspek pengembangan anak
usia 3-4 tahun

\begin{tabular}{cl}
\hline $\mathbf{2}$ & Naik turun tangga tanpa berpegangan \\
\hline $\mathbf{3}$ & Memanjat \\
\hline $\mathbf{4}$ & Berjalan di titian dengan jarak $20 \mathrm{~cm}$ \\
\hline $\mathbf{5}$ & Berlari dengan stabil atau berlari di tempat \\
\hline $\mathbf{6}$ & Senam menirukan gerakan binatang \\
\hline $\mathbf{7}$ & $\begin{array}{l}\text { Menendang, menangkap dan melempar bola } \\
\text { dengan jarak lebih jauh }\end{array}$ \\
\hline $\mathbf{8}$ & Melompat dengan satu kaki bergantian \\
\hline $\mathbf{9}$ & Merayap dan merangkak lurus ke depan \\
\hline $\mathbf{1 0}$ & $\begin{array}{l}\text { Berjingkat (berjalan bertumpu pada ujung } \\
\text { kaki) }\end{array}$ \\
\hline $\mathbf{1 2}$ & $\begin{array}{l}\text { Membedakan permukaan } 5 \text { jenis benda } \\
\text { Menuang (air, biji-bijian) tanpa tumpah }\end{array}$ \\
\hline $\mathbf{1 3}$ & $\begin{array}{l}\text { Memegang benda kecil dengan telunjuk dan } \\
\text { ibu jari }\end{array}$ \\
\hline $\mathbf{1 4}$ & Menggunting sembarangan \\
\hline $\mathbf{1 5}$ & $\begin{array}{l}\text { Melipat kertas mengikuti garis } \\
\text { Membuat garis lurus, vertikal, melengkung }\end{array}$ \\
\hline Sumber : Modul Kegiatan PAUD Non Formal (2008 : 7)
\end{tabular}

Dari teori-teori yang dijelaskan diatas dapat disimpulkan bahwa kemampuan motorik anak usia dini memang sangat peka terhadap stimulan yang diberikan, sehingga anak-anak perlu dilatih dan diberikan materi permainan dan diarahkan dalam hal-hal yang positif agar anak bisa memperoleh kemampuan motorik yang optimal.

\section{METODE}

Penelitian ini dilakukan digabungan beberapa tempat yaitu di Paud Darma wanita Gamping, Campurdarat. Waktu penelitian mulai dilaksanakan pada bulan Juni 2019 sampai Desember 2019. Model pengembangan yang digunakan dalam penelitian ini adalah model pengembangan Research \& Development (R\&D) dari Borg \& Gall (1983: 775).

Subjek penelitian yang terlibat dalam penelitian ini adalah, (a) Subyek uji coba perorangan yaitu 1 ahli pembelajaran PAUD, 1 ahli permainan (b) subjek uji coba kelompok kecil adalah 6 siswa PAUD, (c) subjek uji coba kelompok besar yaitu dengan 30 siswa di PAUD. Data yang diperoleh dari hasil tinjauan ahli berupa data kualitataif dan data kuantitatif. Data kualitatif yaitu diperoleh dari hasil tinjauan ahli yaitu 2 ahli pembelajaran PAUD dan data kuantitatif diperoleh dari uji coba kelompok kecil dan kelompok besar.

\section{HASIL DAN PEMBAHASAN}

Data uji coba diperoleh dari instrument yang berupa angket. Data analisis kebutuhan didapatkan dari guru-guru PAUD, 
dan data evaluasi diperoleh dari 3 ahli yaitu ahli media, ahli pembelajaran penjas PAUD, ahli permainan. uji coba kelompok kecil dan uji coba kelompok besar.

\section{Analisis Kebutuhan}

Analisis kebutuhan yang telah dilakukan diperoleh beberapa data yang digunakan untuk mengetahui permasalahanpermasalahan yang terdapat dalam proses pembelajaran yang dilakukan di PAUD yaitu masih belum optimal pembelajaran yang dilakukan hal ini dapat terlihat dari antusias siswa yang kurang aktif bergerak, kemudian kesulitan gerakan dalam permainan hal ini disebabkan tidak adanya buku panduan yang digunakan sebagai acuan untuk mengajar permainan olahraga ini, untuk itu guru PAUD $\mathrm{k}$ sangat membutuhkan sekali model permainan tersebut. Permainan yang diberikan kepada anak-anak mempunyai tujuan untuk mengasah kemampuan motorik halus anak didik.

\section{Perancangan dan Pengembangan Produk} Perancangan dan pengembangan dilakukan setelah diketahui adanya kebutuhan akan pengembangan serta analisis model pembelajaran sebelumnya.

Draft awal produk pada tahap perancangan produk disusun setelah diketahui adanya kebutuhan pada pengembangan produk ini. Perancangan produk diawali dengan analisis serta literatur terkait dengan model permainan gerak motorik halus. Berikut ini adalah model permainan gerak motorik halus: 1.Menghitung menggunakan jari, 2.Bermain dengan gelang karet, 3 . Tebak bola warna Memakai telunjuk jari, 4. Melempar bola, 5. Bermain dengan kertas, 6. Membedakan besar kecil, 7. Bermain dengan lilin, 8. Membedakan panjang pendek, 9. Membedakan bentuk benda, 10. Pesan berantai, 11. Pengenalan huruf, 12. Mencocokkan gambar dengan angka.13. Permainan Dadu angka. Untuk selanjutnya ada beberapa contoh model.

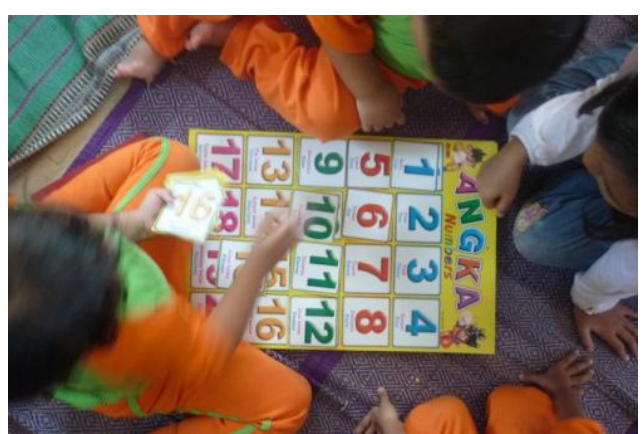

Gambar 1. Salah satu anak sedang melakukan permainan mencocokkan gambar angka

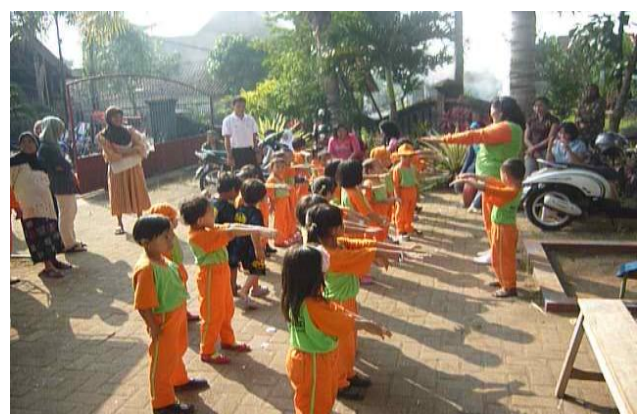

Gambar 2. Anak-anak sedang melakukan pemanasan

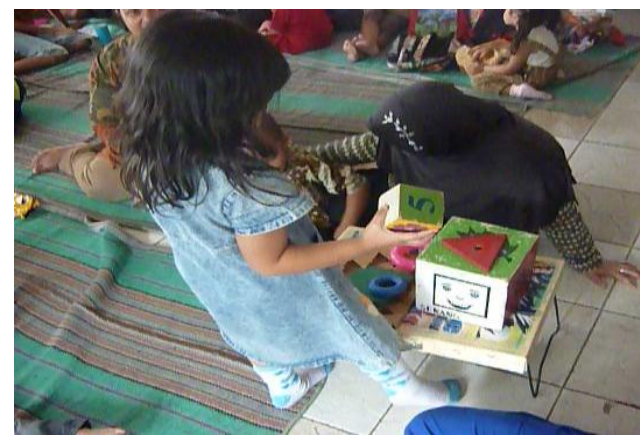

Gambar 3. Anak-anak sedang mendengarkan penjelasan tentang membedakan besar kecil

\section{Data Hasil Uji Coba Kelompok Kecil Dan Uji Coba Kelompok Besar}

Berdasarkan hasil dari analisis kebutuhan dan hasil dari para ahli selanjutnya adalah ke tahapan uji kecil dan uji besar. Secara keseluruhan hasilnya layak digunakan dan dapat diterapkan dengan baik. Adapun hasilnya dapat dilihat pada tabel di bawah ini:

Tabel 2. Hasil Uji Coba Kelompok Kecil

\begin{tabular}{clc}
\hline No & \multicolumn{1}{c}{ Model } & Keterangan Uji Kecil \\
\hline 1 & $\begin{array}{l}\text { Menghitung } \\
\text { menggunakan jari }\end{array}$ & $\begin{array}{c}\text { Model Dilakukan } \\
\text { Dengan Baik }\end{array}$ \\
\hline 2 & $\begin{array}{l}\text { Bermain dengan } \\
\text { gelang karet }\end{array}$ & $\begin{array}{c}\text { Model Dilakukan } \\
\text { Dengan Baik }\end{array}$ \\
\hline
\end{tabular}




\begin{tabular}{llc}
\hline No & \multicolumn{1}{c}{ Model } & Keterangan Uji Kecil \\
\hline 3 & $\begin{array}{l}\text { Tebak bola warna } \\
\text { Memakai telunjuk jari, }\end{array}$ & $\begin{array}{c}\text { Model Dilakukan } \\
\text { Dengan Baik }\end{array}$ \\
\hline 4 & Melempar bola & $\begin{array}{c}\text { Model Dilakukan } \\
\text { Dengan Baik }\end{array}$ \\
\hline 5 & $\begin{array}{l}\text { Bermain dengan } \\
\text { kertas, }\end{array}$ & $\begin{array}{c}\text { Model Dilakukan } \\
\text { Dengan Baik }\end{array}$ \\
\hline 6 & $\begin{array}{l}\text { Membedakan besar } \\
\text { kecil, }\end{array}$ & $\begin{array}{c}\text { Model Dilakukan } \\
\text { Dengan Baik }\end{array}$ \\
\hline 7 & Bermain dengan lilin & $\begin{array}{c}\text { Model Dilakukan } \\
\text { Dengan Baik }\end{array}$ \\
\hline 8 & $\begin{array}{l}\text { Membedakan panjang } \\
\text { pendek }\end{array}$ & $\begin{array}{c}\text { Model Dilakukan } \\
\text { Dengan Baik }\end{array}$ \\
\hline 9 & $\begin{array}{l}\text { Membedakan bentuk } \\
\text { benda, }\end{array}$ & $\begin{array}{c}\text { Model Dilakukan } \\
\text { Dengan Baik }\end{array}$ \\
\hline 10 & Pesan berantai & $\begin{array}{c}\text { Model Dilakukan } \\
\text { Dengan Baik }\end{array}$ \\
\hline 11 & Pengenalan huruf & $\begin{array}{c}\text { Model Dilakukan } \\
\text { Dengan Baik }\end{array}$ \\
\hline 12 & $\begin{array}{l}\text { Mencocokkan gambar } \\
\text { dengan angka }\end{array}$ & $\begin{array}{c}\text { Model Dilakukan } \\
\text { Dengan Baik }\end{array}$ \\
\hline 13 & $\begin{array}{l}\text { Permainan Dadu } \\
\text { angka }\end{array}$ & $\begin{array}{c}\text { Model Dilakukan } \\
\text { Dengan Baik }\end{array}$ \\
\hline
\end{tabular}

Tabel 3. Hasil Uji Coba Kelompok Besar

\begin{tabular}{llc}
.No & \multicolumn{1}{c}{ Model } & Keterangan Uji Kecil \\
\hline 1 & $\begin{array}{l}\text { Menghitung } \\
\text { menggunakan jari }\end{array}$ & $\begin{array}{c}\text { Model Dilakukan Dengan } \\
\text { Baik }\end{array}$ \\
\hline 2 & $\begin{array}{l}\text { Bermain dengan } \\
\text { gelang karet }\end{array}$ & $\begin{array}{c}\text { Model Dilakukan Dengan } \\
\text { Baik }\end{array}$ \\
\hline 3 & $\begin{array}{l}\text { Tebak bola warna } \\
\text { Memakai telunjuk jari, }\end{array}$ & $\begin{array}{c}\text { Model Dilakukan Dengan } \\
\text { Baik }\end{array}$ \\
\hline 4 & . Melempar bola & $\begin{array}{c}\text { Model Dilakukan Dengan } \\
\text { Baik }\end{array}$ \\
\hline 5 & $\begin{array}{l}\text { Bermain dengan } \\
\text { kertas, }\end{array}$ & $\begin{array}{c}\text { Model Dilakukan Dengan } \\
\text { Baik }\end{array}$ \\
\hline 6 & $\begin{array}{l}\text { Membedakan besar } \\
\text { kecil, }\end{array}$ & $\begin{array}{c}\text { Model Dilakukan Dengan } \\
\text { Baik }\end{array}$ \\
\hline 7 & Bermain dengan lilin & $\begin{array}{c}\text { Model Dilakukan Dengan } \\
\text { Baik }\end{array}$ \\
\hline 8 & $\begin{array}{l}\text { Membedakan panjang } \\
\text { pendek }\end{array}$ & $\begin{array}{c}\text { Model Dilakukan Dengan } \\
\text { Baik }\end{array}$ \\
\hline 9 & $\begin{array}{l}\text { Membedakan bentuk } \\
\text { benda, }\end{array}$ & $\begin{array}{c}\text { Model Dilakukan Dengan } \\
\text { Baik }\end{array}$ \\
\hline 10 & Pesan berantai & $\begin{array}{c}\text { Model Dilakukan Dengan } \\
\text { Baik }\end{array}$ \\
\hline 11 & Pengenalan huruf & $\begin{array}{c}\text { Model Dilakukan Dengan } \\
\text { Baik }\end{array}$ \\
\hline 12 & $\begin{array}{l}\text { Mencocokkan gambar } \\
\text { dengan angka }\end{array}$ & $\begin{array}{c}\text { Model Dilakukan Dengan } \\
\text { Baik }\end{array}$ \\
\hline 13 & $\begin{array}{l}\text { Permainan Dadu } \\
\text { angka }\end{array}$ & $\begin{array}{c}\text { Model Dilakukan Dengan } \\
\text { Baik }\end{array}$ \\
\hline & & \\
\hline
\end{tabular}

Pembahasan dalam penelitian ini menjadi topik selanjutnya. Hasil penelitian diatas akan dilanjutkan pembahasan dengan penelitian lain yang relevan. hasil dari penelitian dan pengembangan model pembelajaran permainan ini memberikan hasil yang positif mengingat dalam proses uji coba kelompok kecil dan uji coba kelompok besar dapat dilaksanakan dengan baik. penelitian dari Rusfriyanti (2013) menyebutkan bahwa Pembelajaran menggunakan alat-alat sederhana sangat dibutuhkan guru. Melalui pengembangan model pembelajaran ini, dapat membantu para guru pendidikan jasmani dalam mengajarkan siswa gerak-gerak multirateral dengan memadukan berbagai macam alat yang dapat dimodifikasi.

\section{KESIMPULAN}

Berdasarkan hasil penelitian yang dilakukan maka dapat ditarik kesimpulan bahwa model permainan yang dikembangkan sudah bagus namun perlu dilakukan penelitian terusan lagi dengan menambahkan uji efektivitas setelah uji coba kelompok besar.

Pengembangan ini akan lebih optimal lagi jika pengembangan permainan ini dilengkapi dengan multimedia seperti gerakan animasi atau video sehingga pembaca akan mendapatkan gambaran dan pemahaman yang tepat dan komprehensif. Seperti hasil penelitian dari Darmawan (2017) bahwa penelitian dengan pengembangan berbasis tekhnologi memberikan kontribusi positif dalam mendukung pembelajaran. namun secara keseluruhan model permainan yang telah dikembangkan berdasarkan uji coba kelompok, dapat digunakan untuk mengasah motorik halus.

\section{DAFTAR PUSTAKA}

Borg. W. R \& Gall, M. D. (1983) Educational Research An Introduction. New York: Longman.

Cameron, C. E., Brock, L. L., Murrah, W. M., Bell, L. H., Worzalla, S. L., Grissmer, D., \& Morrison, F. J. (2012). Fine Motor Skills and Executive Function Both Contribute to Kindergarten Achievement. Child Development. https://doi.org/10.1111/j.14678624.2012.01768.x

Darmawan, Arief \& M. Asmawi. (2017). Development Of Basic Movement Model Based On Interactive Multimedia For Elementary Students. Journal of Indonesian Physical Education and Sport. Vol. 3, No.2, 2017, p 95-109: PPs UNJ Publisher Ghassabian, A., Sundaram, R., Bell, E., Bello, 
S. C., Kus, C., \& Yeung, E. (2016). Gross motor milestones and subsequent development. Pediatrics. https://doi.org/10.1542/peds.20154372

Harvey, A. R. (2017). The Gross Motor Function Measure (GMFM). Journal of Physiotherapy. https://doi.org/10.1016/j.jphys.2017.05. 007

Kawai, R., Markman, T., Poddar, R., Ko, R., Fantana, A. L., Dhawale, A. K., ... Ölveczky, B. P. (2015). Motor Cortex Is Required for Learning but Not for Executing a Motor Skill. Neuron. https://doi.org/10.1016/j.neuron.2015.0 3.024

Krampe, R. T. (2002). Aging, expertise and fine motor movement. Neuroscience and Biobehavioral Reviews. https://doi.org/10.1016/S01497634(02)00064-7

Langendorfer, S. (2016). Test of Gross Motor Development. Adapted Physical Activity Quarterly. https://doi.org/10.1123/apaq.3.2.186

McDowell, B. (2008). The gross motor function classification system Expanded and revised. Developmental Medicine and Child Neurology. https://doi.org/10.1111/j.14698749.2008.03104.x

Piek, J. P., Dawson, L., Smith, L. M., \& Gasson, N. (2008). The role of early fine and gross motor development on later motor and cognitive ability. Human Movement Science. https://doi.org/10.1016/j.humov.2007.1 1.002

Pitcher, T. M., Piek, J. P., \& Hay, D. A. (2003). Fine and gross motor ability in males with ADHD. Developmental Medicine and Child Neurology. https://doi.org/10.1017/S00121622030 00975

Rusfriyanti, R.D. (2013). pengembangan model pembelajaran gerak dasar lompat bagi siswa kelas II sekolah dasar, Jakarta: PPS UNJ.

Sun, S. H., Sun, H. L., Zhu, Y. C., Huang, L. chi, \& Hsieh, Y. L. (2011). Concurrent validity of Preschooler Gross Motor Quality Scale with Test of Gross Motor
Development-2. Research in Developmental Disabilities. https://doi.org/10.1016/j.ridd.2011.01.0 07

Westendorp, M., Houwen, S., Hartman, E., \& Visscher, C. (2011). Are gross motor skills and sports participation related in children with intellectual disabilities?

Research in Developmental Disabilities.

https://doi.org/10.1016/j.ridd.2011.01.0 09

Wolpert, D. M., Diedrichsen, J., \& Flanagan, J. R. (2011). Principles of sensorimotor learning. Nature Reviews Neuroscience. https://doi.org/10.1038/nrn3112

Wolpert, D. M., Ghahramani, Z., \& Flanagan, J. R. (2001). Perspectives and problems in motor learning. Trends in Cognitive Sciences. https://doi.org/10.1016/S13646613(00)01773-3 